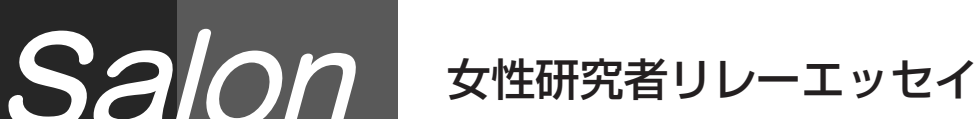

\section{Take it easy!}

\section{斉藤美佳子（東京農工大学工学研究院）}

これまで多くの女性研究者の方々が，このリレーエッセイ を執筆されており，今更私ごときが何か意味のあることを書 くことができるのだろうか，と悩みました。すでに何人かの 先生方がご指摘されているように，女性研究者の少なかった 時代では，先輩方のご苦労も一方ならぬものもあったかと思 いますが，その方々のおかげで，男女雇用機会均等法の施行， 男女共同参画が推進されるようになって以来，いろいろな女 性研究者支援制度が整備されつつあり，私個人としては特に 女性だから，という理由で不公平さ，あるいは，不条理さを 感じたことはほとんどありません，いや，多少はあったのか もしれませんが，私自身が鈍いだけで感じなかっただけかも しれません，いずれにせよ，当の本人が感じないくらい幸せ な時代になったのだと思い, 先人の努力に改めまして感謝申 しあげます。

私は幼少のころから女の子らしい子供ではありませんでし た. 女の子独特のネチネチした話が苦手で，男の子のサバサ バしたところが気に入っていました. 恐らく, 小学校で初め てであろう黒いランドセルを背負い, 女の子私一人が野球千 ームに所属しており，さながら「男の子」状態でした。事実， 隣のクラスの女の子からバレンタインデーのチョコレートを もらったほどです。小学生の時には体力的にも男の子と互角 かそれ以上の自信がありましたので，あまり意識していたつ もりはありませんでしたが，このころから，男の子に負けて たまるかといった気持が強かったのかもしれません.

大学は何の迷いもなく理科系に進みました. 私達の時代で, 女子学生の割合は 1 割程度でしたが, それでも化学系は女子 学生の占める割合は高かった方でした。研究室に配属された 時にも研究室内に女子学生は私一人でして, 当時は, 大学院 に進学する女子学生はそれほど多くなく, やはり女子学生は 私一人でした。徹夜や実験量では誰にも負けないという自信 はありましたが，実験装置を組み立てるときに必要な，ボル ト, ナット, ワッシャー, スパナ, 六角レンチなど, 男子学 生が知っていた工具類の名称を私だけ知らないことにショッ クを受けていました。また, 実験に必要な電子回路を組んで いた時，銀色をしているものはすべて電気を通すであろうと いう勝手な考えの下，たまたま，丁度よい径のワッシャーが 近くにあったので長さの足りないところで使用したところ， それを見た先輩に，『なんだ，それー』とからかわれ，必要 以上に怒って䚻ってしまったこともありました，今にして思 えばそれほど怒るようなことではなく，素直に知らなかった ことを認め，教えを請えばよかっただけであったと思います。 幸い，その先輩とは今でも仲良くさせていただいております が，やはりこのときも全身に力を込めて精一杯背伸びをして
いたのだと思います。

日曜日の夜 7 時半にNHKで「ダーウインが来た! 生きも の新伝説」という番組があり，毎週見ています。そこでは， これまでに見たことがない生きものたちの世界を映像で見る ことができます。ここで気づくことは，多くの雄はあの手こ の手で雌の気を引きつけようとそれは涙ぐましいまでの努力 をします。しかし，無事に努力が報われ雌の気を引くことに 成功すると間もなく，新たに別の雌へのアタックを開始しま す。そのため，雌は一匹で出産し育児をします。もちろん， 全ての動物がそうであるわけではありません．群れをなして 行動する動物はお互い助け合いながら生活していきます。動 物の場合は，種の保存のため子孫を残すためにいたし方ない とはいえ，『父親の役割は？』と思ってしまいます。しかし， 一方で, 出産は基本的には雌にしかできないことであり, こ のことは生きるものすべてに共通のことであり，おのずと役 割が生ずるのだと理解することができます，人間も同じだと 思います。 もちろん, 研究における人事, 研究費の獲得等で 性差による差別があってはならないことであり, 素直に, 一 研究者としての品性, 人格, 業績等を評価するだけでいいの ではないかと思います。研究者に男性も女性もなく, 等しく 各々の考え方，研究人生を進めば良いと思います。その時に， 女性研究者は無理に男性と張り合うのではなく, もっと肩の 力を抜いて，まさにTake it easy!でいいのではないかと思う のです。ひょっとしてこれは自分自身に言い聞かせているの かもしれませんが.

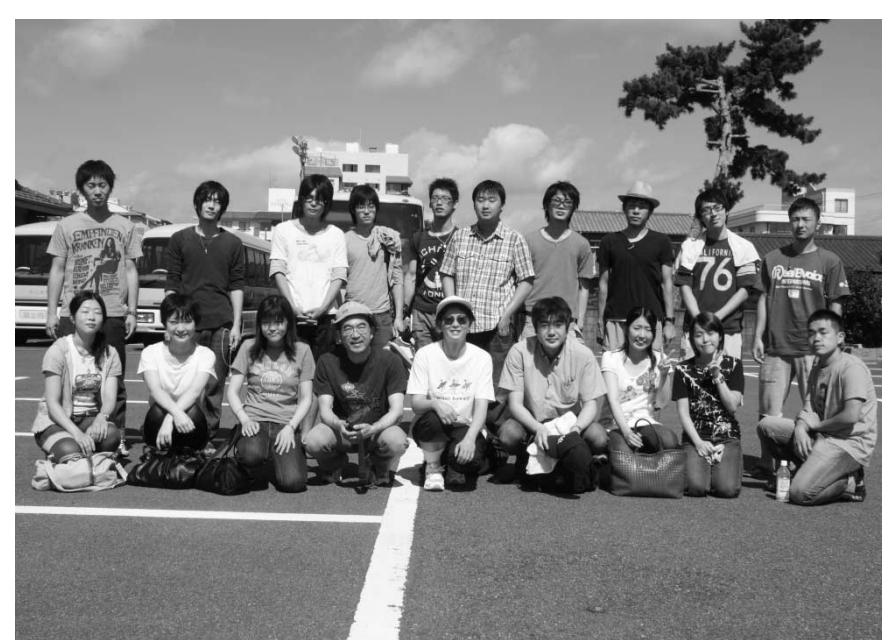

研究室の夏の旅行で千葉県の白子海水浴場に行ったときの写真で す。真ん中でサングラスをかけ白い帽子をかぶっているのが私で す. 